\title{
Molecular Management of Chronic Lymphocytic Leukemia: Towards a Chemotherapy-Free Approach
}

\author{
Nilgun SAYINALP, Ibrahim C. HAZNEDAROGLU \\ Hacettepe University Faculty of Medicine Department of Hematology, Ankara, TURKEY
}

\begin{abstract}
B-cell receptor (BCR) signaling is implicated as a pivotal pathway in tumorigenesis in B-cell malignancies. The inhibitors of Bruton's tyrosine kinase (BTK) and phosphatidylinositide 3-kinase-delta (PI3K), modulating BCR signaling, have included into the clinical studies and demonstrated high response rates in B-cell lymphoproliferative diseases such as chronic lymphocytic leukemia (CLL). The imbalance between proliferation and apoptosis is the novel target in the treatment of CLL. The newly developed targeted molecular agents such as idelalisib (CAL-101 or GS-1101), ibrutinib (PCl-32765), BCL-2 inhibitors (ABT-263 (navitoclax) and ABT-199 (venetoclax)), chimeric antigen receptors (CART19 cells), novel monoclonal antibodies, and immunomodulatory drugs try to balance between survival and programmed cell death in the pathobiology of the disease. The ongoing clinical trials focusing on the combinations of kinase inhibitors with monoclonal antibodies and other pro-apoptotic agents may lead to the chemotherapy-free protocols for the indolent incurable long disease course of B-CLL. With the greater clinical experience following more widespread use of novel molecules, the optimal combination therapies in the treatment-naive and relapsed/refractory patients will be determined, resulting in more individualized therapeutic strategies for patients with CLL.
\end{abstract}

Keywords: B-cell receptor, Idelalisib, Ibrutinib, Chronic lymphocytic leukemia

\section{ÖZET}

\section{Kronik Lenfositik Löseminin Moleküler Yönetimi: Kemoterapiden Bağımsız Bir Yaklaşıma Doğru}

B hücre reseptör (BHR) sinyalleri, B hücreli malignansilerdeki tümör gelişiminde kavşak yolak görevi görürler. BHR sinyallerini ayarlayan Bruton tirozin kinaz (BTK) inhibitörleri ve fosfatidilinositol 3-kinaz-delta (PI3K) bir çok klinik çalışmada yer almış ve kronik lenfositik lösemi (KLL) gibi B hücreli lenfoproliferatif hastalıklarda yüksek yanıt oranları göstermişlerdir. KLL tedavisindeki yeni hedef proliferasyon ve apoptoz arasındaki dengedir. Yeni geliştirilen hedefe yönelik ajanlardan idelalisib (CAL-101 veya GS-1101), ibrutinib (PCl-32765), BCL2 inhibitörleri (ABT-263 (navitoclax) ve ABT-199 (venetoclax)), kimerik antijen reseptörleri (CART19 hücreleri), yeni monoklonal antikorlar ve immünmodülatör ilaçlar, hastalığın patobiyolojisindeki programlanmış hücre ölümü ve sağkalımı arasındaki dengeyi sağlamaya çalışmaktadıllar. Kinaz inhibitörleriyle monoklonal antikor kombinasyonları ve diğer pro-apoptotik ajanlara odaklanmış halen süren kinik çalışmalar sayesinde B-KLL'nin uzun ve indolen hastalık seyrine yönelik kemoterapiden bağımsız tedavi protokolleri ortaya çıkabilir. Yeni moleküllerin yaygın kullanımı sonucu ortaya çıkacak büyük klinik tecrübe ile hiç tedavi verilmemiş ve relaps/refrakter hastalara yönelik optimal kombinasyon tedavileri belirlenebilecek, böylece KLL hastalarında daha bireyselleştirilmiş tedavi stratejleri ortaya konabilecektir.

Anahtar Kelimeler: B-hücre reseptörü, Idelalisib, Ibrutinib, Kronik lenfositik lösemi 


\section{INTRODUCTION}

Chronic lymphocytic leukemia (CLL), as an indolent and incurable form of clonal leukemic disease, typically occurs in the elderly patients with co-morbidities and has a long lasting heterogenous disease course. The clinical stage of CLL disease, the fitness of the patient, the genetic risk of the leukemia, and the treatment situation (frontline versus second-line, response vs non-response to the last treatment) are the main factors in the clinical decision making in CLL. The treatment, particularly with the chemotherapeutic cytotoxic drugs having numerous adverse effects, should not be worse than the CLL disease itself. The interactions between the comorbidity and therapy of CLL suggested that the durable control of the hematologic disease is most critical to improve overall outcome of patients with increased comorbidity. Hence, the clinical disease presentations are heterogenous in CLL and the treatment decision should be based on a patient-centered individual basis rather than the disease-based fixed approach. Therefore, novel less-toxic therapeutic agents are needed, particularly for the CLL patients with comorbidities or high-risk cytogenetic abnormalities. ${ }^{1}$ Since the significant therapy-related toxicities and the indolent/ incurable nature of CLL, the treatment algorithms will continue to be revised to a more personalized approach in order to treat with improved efficacy devoid of unnecessary toxicity. Targeted molecular agents offer much promise in terms of efficacy, toxicity, and oral availability. They will change the management of patients with CLL. The main pharmacobiological basis of novel therapeutic molecules in CLL is that their mechanism of action targets a relatively specific signaling abnormality or redirects the immune system against leukemic cells. Immune reconstitution remains an enticing prospect in CLL, as malignant B cells should be particularly susceptible to a T cell-mediated attack. The pharmacological inhibitors targeting different kinases of B-cell receptor (BCR) signalling cascade, such as Bruton tyrosine kinase (BTK) and phosphatidylinositol-3-kinase (PI3K) have been developed. ${ }^{1-3}$ Introductions of those BCR kinase inhibitors have the potential to eliminate the role of chemotherapy in the treatment of CLL. ${ }^{1,2}$ Novel molecular agents such as BCL-2 inhibitors (ABT-
263 (Navitoclax) and ABT-199 (Venetoclax), chimeric antigen receptors (CART19 cells), novel monoclonal antibodies, and immunomodulatory drugs for the pharmacobiological management of CLL are depicted in Table 1.

The aim of this review is to outline the pharmacobiology and clinical data of the novel molecular agents, particularly ibrutinib (PCI-32765) inhibiting BTK2 and idelalisib (CAL-101 or GS-1101) inhibiting PI3K3, effective in the clinical care of CLL.

\section{CLL Management at the Molecular Level}

$\mathrm{BCR}$ is essential for normal B-cell development and maturation. On the other hand, BCR signaling is implicated as a pivotal pathway in tumorigenesis. ${ }^{4}$ Chronic activation of the BCR engages multiple intracellular pathways. BCR signaling can be targeted with new, small molecule inhibitors of the spleen tyrosine kinase (Syk), BTK, or phosphoinositide 3'-kinase (PI3K) isoform p110delta15 (PI3Kdelta). PI3K/AKT pathway antagonizes apoptosis, through interfering with downstream proteins. This activation of Akt leads to increased survival in a dual fashion: first, by inhibiting activation

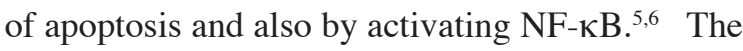
cytotoxicity and mechanisms of cell death induced by the delta isoform-specific phosphatidylinositide 3-kinase (PI3K) inhibitor, idelalisib, in combination with the HDI, panobinostat (LBH589) and suberoylanilide hydroxamic acid (SAHA) have been investigated. ${ }^{7} \mathrm{PI} 3 \mathrm{~K} \alpha$ and PI3K $\beta$ are ubiquitously expressed in all cells and tissues, whereas PI3K $\gamma$ and PI3K $\delta$ are mainly enriched in leukocytes and $\mathrm{PI} 3 \mathrm{~K} \delta$ is the primary PI3K isoform in leukocytes. PI3K $\delta$ is under the control of RTKs and antigen receptors. Class I PI3Ks produce the second messenger PIP3, which promotes cell survival, proliferation, metabolism, motility and differentiation. Aberrant PI3K activities are frequently observed in many types of cancers through different mechanisms including (but not limited to) hyperactivated RTKs, mutant Ras, functional loss of PTEN and activating mutations and/or overexpression of PI3K isoforms. ${ }^{8}$ CLL management at the molecular level is illustrated in Figure 1. 
International Journal of Hematology and Oncology

\begin{tabular}{|c|c|c|}
\hline Drug/ Pharmacological Agent & Molecular Target(s) & Current Clinical Trials \\
\hline \multicolumn{3}{|l|}{ Kinase inhibitors } \\
\hline Idelalisib (CAL-101, GS-1101) & PI3K $\delta$ & Phase III \\
\hline Ibrutinib (PCl-32765) & BTK & Phase III \\
\hline AMG 319 & PI3Kס & Phase I \\
\hline $\mathrm{IPI}-145$ & $\mathrm{Pl} 3 \mathrm{~K} \gamma$ and $\delta$ & Phase I/III \\
\hline CC-292 (AVL-292) & BTK & Phase I \\
\hline ONO-4059 (GS-4059) & BTK & Phase II \\
\hline GS-9973 & Syk & Phase II \\
\hline CC115 & mTOR and DNA-PK & Phase I \\
\hline Dasatinib & BCR-ABL and SRC kinases & Phase II \\
\hline Fostamatinib & Syk & Phase I/III \\
\hline \multicolumn{3}{|l|}{ Monoclonal Antibodies } \\
\hline Obinutuzumab (GA101) & $\mathrm{CD} 20$ & Phase III \\
\hline Bl 836826 (moAb 37.1) & CD37 & Phase I \\
\hline TRU-16 (otlertuzumab) & CD37 & Phase I/II \\
\hline Blinatumomab (MT103/MEDI538) & CD19 & Phase I \\
\hline \multicolumn{3}{|l|}{ BCL-2 Antagonists } \\
\hline ABT-199 (venetoclax) & BCL-2 & Phase $\|/\| \|$ \\
\hline \multicolumn{3}{|l|}{ Immunomodulators } \\
\hline Lenalidomide & Multiple & Phase III \\
\hline \multicolumn{3}{|l|}{ CARTs } \\
\hline CTL019 & CD19 & Phase I/II \\
\hline
\end{tabular}

PI3K-mediated phosphorylation activates the serine/threonine kinase AKT and mTOR. PI3Ks are lipid kinases that regulate diverse cellular processes including proliferation, adhesion, survival, and motility. Dysregulated PI3K pathway signaling occurs in one-third of human tumors. ${ }^{9}$ Over-expression of PI3K/AKT contributes to the pathogenesis of various lymphoid malignancies, including CLL. Inhibition of PI3K results in cellular death through apoptosis. PI3K-delta subunit could exhibit significant clinical activity in CLL. Idelalisib (CAL-101, GS-1101) and IPI-145 (INK-1147) are the oral PI3K-delta inhibitors in the drug development stages. ${ }^{10}$ Idelalisib and fostamatinib which inhibit the delta isoform of PI3 kinase (PI3Kd) and spleen tyrosine kinase (Syk) have shown significant clinical activity. ${ }^{11}$ Idelalisib (GS-1101) is an orally bioavailable, potent, and selective inhibitor of the p1108 isoform that is currently under clini- cal evaluation in B-cell malignancies. ${ }^{5}$ Inhibition of PI3K has been demonstrated to produce durable treatment responses and improved survival outcomes in clinical trials involving patients with indolent forms of NHL. PI3K inhibited by idelalisib can produce clinical responses in CLL. ${ }^{1,12}$ Life cycles of CLL cells involve homing and egression in the patients. The migration of leukemic cells from the peripheral blood to the lymph nodes, spleen, and bone marrow, where they are become activated by micro-environmental stimuli, leads to survival and proliferation. Inhibition of PI3K $\delta$ may interfere with this cycling at various levels, resulting in the mobilization of tissue-resident CLL cells into the blood and blocking re-entry to the stroma. ${ }^{13}$

CLL cells in the lymph node and bone marrow microenvironments demonstrate higher levels of BCR and NF- $\kappa$ B signaling. ${ }^{14}$ Mechanisms of BCR activation may include chronic antigenic drive by 


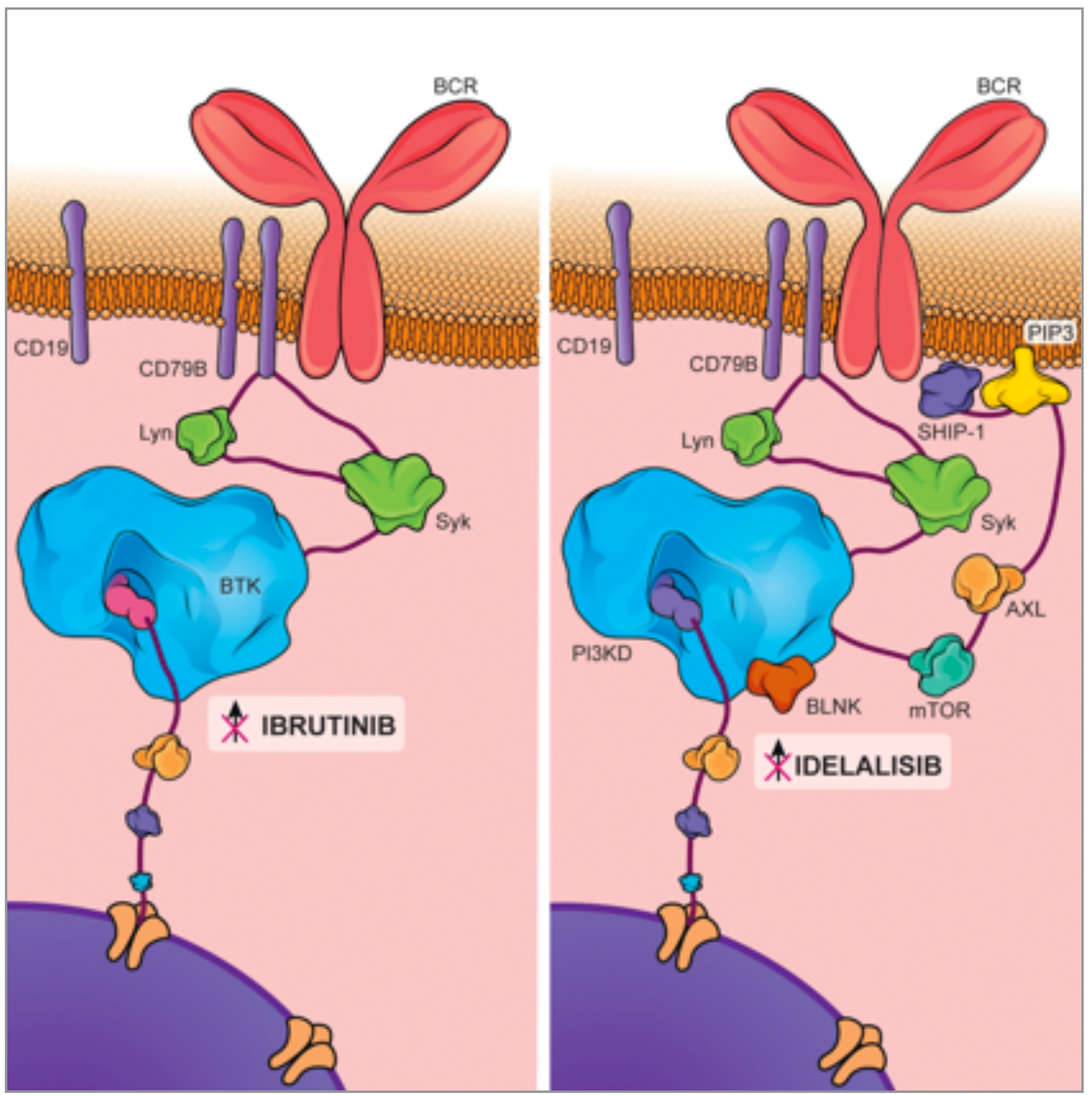

Figure 1. Chronic lymphocytic leukemia (CLL) management at the molecular level. B-cell receptor (BCR) signaling is implicated as a pivotal pathway in tumorigenesis. Chronic activation of the BCR engages multiple intracellular pathways. BCR signaling can be targeted with the drugs [lbrutinib (against BTK) or idelalisib (against PI3KD)] to control neoplastic disease.

microbial or viral antigens, auto-stimulation of Bcells by self-antigens, and activating mutations in the intracellular components of the BCR pathway. ${ }^{4}$ B-lymphocytes have critical functions in the immune response, including antigen presentation, antibody production, and cytokine release. BCR, which is activated by binding to antigen, can induce receptor aggregation together with the activation of multiple tyrosine kinases and downstream signaling pathways. ${ }^{4}$
BTK is a Tec family cytoplasmic tyrosine kinase that is a key component of BCR signaling pathway and is critical for normal B cell development, differentiation, proliferation and survival. BTK is a 659-amino-acid protein that contains five signaling domains and has diverse partner molecules. ${ }^{15}$ BTK transmits, diversifies, and amplifies signals from a wide variety of surface molecules that cells use to communicate with their microenvironment. BTK is a central signaling node mediating the nourish- 
ing and protective effects of the tumor microenvironment. ${ }^{16} \mathrm{BTK}$ is also essential for the homing of MCL cells into lymphoid tissues, and its inhibition results in an egress of malignant cells into peripheral blood. ${ }^{17}$ The absence of BTK predominantly affects B cell function. In the absence of BTK, $\mathrm{BCR}$ signaling is insufficient to induce late transitional $\mathrm{B}$ cells to differentiate into mature peripheral B cells. BCR signaling pathway genes are constitutively increased in B cell tumors, manageable via the therapeutics targeting BTK. BTK inhibition had decreased DNA synthesis and prosurvival signal from stromal cells and cytokines. ${ }^{15,18}$

Pathobiological expression of the B-cell receptor (BCR) signaling can cause disease progression in the malignant B-cell neoplastic diseases. ${ }^{19}$ Bruton's tyrosine kinase (BTK) has a pivotal role in the BCR signaling. Normal B lymphocytes receive signals from $\mathrm{BCR}$ that are triggered by binding of the BCR to an external antigen. Tonic signaling through the BCR provides growth and signals to CLL cells, and plays an important role in the pathogenesis and progression of the disease. ${ }^{20}$ BTK is a cytoplasmic tyrosine kinase transmitting neoplastic signals from the BCR and tissue homing receptors. ${ }^{21}$ BTK inhibitor ibrutinib is a novel targeted-therapeutic agent which serves as a covalent irreversible inhibitor of BTK. ${ }^{22}$ Bruton tyrosine kinase, have generated the most promising early results in clinical trials including predominately refractory CLL where durable disease control has been observed. ${ }^{23-29}$ BTK is a critical kinase for CLL development and expansion and thus an important target of ibrutinib. ${ }^{30}$ Ibrutinib causes an early redistribution of tissue-resident CLL cells into the blood, with rapid resolution of enlarged lymph nodes, along with a surge in lymphocytosis. After weeks to months of continuous ibrutinib therapy, the growth- and survival-inhibitory activities of ibrutinib result in the normalization of lymphocyte counts and remissions in a majority of patients with CLL. ${ }^{31}$

Ibrutinib can induce the redistribution of malignant B cells from tissue sites into the peripheral blood together with the rapid resolution of enlarged neoplastic lymph nodes. ${ }^{21}$ Ibrutinib significantly alters the composition of the tumor microenvironment in CLL, affecting soluble as well as cellular molecular elements. ${ }^{32}$ Ibrutinib does not cause myelosuppression. ${ }^{22}$ With continuous ibrutinib therapy, growthand survival-inhibitory activities of ibrutinib could result in the normalization of lymphocyte counts and remissions in the patients with B-cell neoplastic diseases. Ibrutinib is the first BTK inhibitor that is being used and approved in the clinical practice with the most mature clinical data. ${ }^{33}$ The drug was designed as a selective and irreversible inhibitor of the BTK protein, and it inhibits signal transduction from the BCR and blocks activation of B cells. ${ }^{18}$

Ibrutinib can effectively inhibit neoplastic pathways that promote tumor cell activation and proliferation..$^{2,34,35}$ Herman and coworkers ${ }^{16}$ evaluated the in vivo effects of ibrutinib, the BTK inhibitor on tumor cell activation and proliferation in the peripheral blood, lymph nodes, and bone marrow of the patients with CLL. ${ }^{16}$ They detected a rapid and sustained down-regulation of BCR and NF-kap$\mathrm{paB}$ signaling in CLL cells from both the peripheral blood and tissue compartments during ibrutinib treatment. In their study, ibrutinib significantly decreased tumor proliferation and expression of surface activation markers CD69 and CD86 independent of the well-known CLL prognostic factors such as IGHV mutational status,

\section{Anti-Neoplastic Activities of Novel Molecular Agents in CLL}

Multiple pathobiological factors can contribute to BCR dysregulation in CLL. BCR activation can be influenced by the immunoglobulin structure, the expression and mutations of adaptor molecules, the activity of kinases or phosphatases and the levels of microRNAs. ${ }^{36}$ The crosstalk of BCR with other signalling pathways (NF-kappaB, adhesion, chemokine signalling) are also evident. ${ }^{36} \mathrm{PI} 3 \mathrm{~K}$ inhibitors regulate pathway activities in both cancer and stromal cell populations. ${ }^{37}$ Key pathways orchestrated by PI3Kd and turned on in B-cell malignancies upon BCR activation include membrane trafficking, AKT/mTOR, MAPK, and NF-kB. ${ }^{12,23}$ AKT is the best-characterized downstream effector of PI3Kd and is the central modulator of PI3Kregulated oncogenic signaling. Many oncogenic effectors downstream of AKT play critical roles in regulating cell cycle and cell survival, DNA repair (MDM2 and p53), chemoresistance (NF-kB), and 
energy metabolism (mTOR); many of these targets are inhibited by pan-PI3K or PI3Kd-specific inhibitors. ${ }^{38}$ Ibrutinib inhibits activation and proliferation of CLL cells in vivo. On-target effects of BTK inhibition in tissue-resident CLL cells were shown. Blocking cell proliferation via inhibition of BTK-mediated signaling may contribute to clinical responses in ibrutinib-treated patients. ${ }^{39}$ Binding site between ibrutinib and BTK is well described.

The chemokines in tumor cell-microenvironment interactions represent a target for treatment of CLL. ${ }^{40}$ Chemokine receptors expressed on CLL cells regulate the migration of the leukemia cells within the bone marrow, lymphoid organs in collaboration with chemokines. Furthermore, chemokines produced in distinct tissue microenvironments sustain migration of mature lymphocytes in lymphoglandula. Chemokines form a pro-survival circuitry by regulating leukocyte trafficking, maintaining extended lymphocyte survival. ${ }^{40} \mathrm{~A}$ potentially dangerous subpopulation of CLL cells equipped to migrate to tissue and receive a proliferative stimulus. ${ }^{41}$ In addition, PI3Kd regulates B-cell responses to CD40-ligand, B-cell activating factor (BAFF), IL4, and to the homing chemokines CXCL12/13, ${ }^{2,39}$ The expression of chemokines such as C-C motif ligand 3 and 4 (CCL3/4), as well as stroma-/Tcell-produced factors, including CD40L, TNFa, IL6, and IL10, was also reduced. ${ }^{3,35}$ Idelalisib may thus simultaneously target the malignant B cells by inhibiting their response to stromal factors and the tumor niche by limiting its ability to support the tumor cell growth. ${ }^{42}$ Ibrutinib inhibits the migration of CLL cells in chemokine gradients. Chemokine signaling is blocked by ibrutinib so that the neoplastic migration of the B-cells is impaired. ${ }^{43}$

The reduction of tissue disease burden by ibrutinib is due more to CLL cell death and less to egress from nodal compartments. ${ }^{44}$ Moreover, rapid and sustained reduction of the cellular activation and tumor proliferation has been shown to be achieved by ibrutinib in all of the anatomic compartments related to the neoplastic development of CLL disease course. ${ }^{38}$ Ibrutinib may alter the composition of the bone marrow microenvironment lead to a transient increase in circulating CLL cells consistent with the efflux of activated cells from the tissue compartments leading to the reduction in lymphadenopathy. ${ }^{28}$ Ibrutinib-induced early-onset lymphocytosis ${ }^{45}$ develops within hours due to the release of previously activated resident cells from the tissue microenvironments. The rapid onset of the lymphocytosis and the dramatic defect in the adhesion process suggested that ibrutinib directly interferes with an intracellular signaling network required for cell adhesion. ${ }^{46}$ In vitro idelalisib reduced CLL migration beneath a layer of bone marrow-derived stromal cells, inhibited CLL adhesion to stromal and endothelial cells, and decreased chemotaxis toward CXCL12 and CXCL13. These observations are consistent with the rapid decrease in lymph node size and increase in lymphocytosis in idelalisib-treated patients and are a possible indication of tumor cells being separated and migrating away from the tumor niche..$^{42,47}$ No cases of ibrutinib-induced leukostasis were reported in subjects with CLL/SLL receiving ibrutinib, although subjects with a high number of circulating malignant cells ( $>400.000 \mathrm{k} / \mathrm{uL}$ ) should be closely monitored. In subjects with CLL receiving ibrutinib in combination ${ }^{48}$ with chemoimmunotherapy or immunotherapy, lymphocytosis appeared to occur in lower incidence and at lesser magnitude. The lymphocyte counts of the majority of CLL patients return to baseline lymphocyte values by the end of cycle $5 .{ }^{49,50}$ Idelalisib, like other novel agents targeting the B-cell-receptor signaling pathway, has been shown to cause lymphocytosis when it is administered as a single agent. The addition of rituximab to idelalisib blunted and shortened the duration of the lymphocytosis, which confirmed the findings of a previous phase 1 study. In contrast, there was a sustained increase in the absolute lymphocyte count in the placebo group starting at week 24 , which coincided with the completion of rituximab therapy. As per the modified IWCLL guidelines, this rise in the lymphocyte count was not considered to be disease progression. ${ }^{47,51}$

\section{Clinical Trials of Molecular Agents in CLL}

In the phase 1 trial47, idelalisib, a selective inhibitor of the lipid kinase PI3Kdelta, has been evaluated in 54 patients with relapsed/refractory CLL with adverse characteristics including bulky lymphadenopathy (80\%), extensive prior therapy 
(median 5 [range 2-14] prior regimens), treatmentrefractory disease (70\%), unmutated IGHV (91\%), and del17p and/or TP53 mutations (24\%). In this study $^{47}$, the patients with CLL in this trial were treated at 6 dose levels of oral idelalisib (range 50$350 \mathrm{mg}$ once or twice daily) and remained on continuous therapy until progression. Idelalisib treatment resulted in nodal responses in $81 \%$ of patients in this study. The overall response rate was $72 \%$, with $39 \%$ of patients had the partial response. The median progression-free survival those CLL patients was 15.8 months. ${ }^{47}$

O'Brien et al present the first clinical trial of idelalisib with rituximab for the initial therapy of CLL in patients with a median age of 71 years, $42 \%$ of whom had advanced-stage disease. The overall response rate in this phase II study is $97 \%$, with $19 \%$ being complete responders, none of whom have progressed to date. The progression-free survival (PFS) is an impressive $83 \%$ at 36 months, with only 4 events of disease progression, despite only 23 of 64 patients currently continuing on idelalisib. Among the highest-risk TP53-mutated patients $(n=9)$, the overall response rate is $100 \%$ and none have progressed, consistent with the known excellent activity of idelalisib in relapsed patients in this high risk group. Although this was a phase 2 study, these results compare very favorably with the current standard of care for this patient populationobinutuzumab chlorambucil - which has a median PFS of 29.2 months in a phase 3 study $^{51}$, and are similar to the smaller phase $1 \mathrm{~b} / 2$ study of ibrutinib, which showed a PFS of $96 \%$ at 30 months, 4 with only 2 TP53-mutated patients. These results certainly justify registration trials of idelalisib in this upfront setting. ${ }^{50}$

The combination of idelalisib and rituximab, as compared with placebo and rituximab, significantly improved progression-free survival, response rate, and overall survival among patients with relapsed CLL who were less able to undergo chemotherapy in a multicenter, randomized, double-blind, placebo-controlled, phase III 116 study.$^{52}$ Eligible patients needed to have disease progression within 24 months of their last treatment, previously received anti-CD20 therapy or $\geq 2$ prior cytotoxic therapies and had current contraindications to cytotoxic therapy. The authors randomly assigned
220 CLL patients with decreased renal function, previous therapy-induced myelosuppression, or major coexisting illnesses to receive rituximab 375 $\mathrm{mg} / \mathrm{m}^{2}$ intravenously for the first cycle and at 500 $\mathrm{mg} / \mathrm{m}^{2}$ intravenously on subsequent cycles (cycles were every 2 weeks for 5 doses, then monthly for 3 doses) and either idelalisib at a dose of $150 \mathrm{mg}$ or placebo twice daily. The primary end point in their study was progression-free survival. There were no statistically significant differences in baseline characteristics between the groups, with $78 \%$ of all patients being $\geq 65$ years old, $>80 \%$ having unmutated IGHV, $>40 \%$ having a $17 \mathrm{p}$ deletion, and $85 \%$ having a Cumulative Illness Rating Scale (CIRS) score of more than 6 . Based on the results of this study, The 24-week PFS was $93 \%$ and $46 \%$ for the idelalisib and placebo groups, respectively, which resulted in the trial being stopped early due to treatment efficacy. The median PFS was 5.5 months in the placebo group and was not reached in the idelalisib group $(\mathrm{p}<0.001)$. The median duration of idelalisib and placebo treatment was 3.8 and 2.9 months, respectively, though $81 \%$ of idelalisib patients were continuing treatment at study termination compared to $52 \%$ of patients receiving placebo. Disease progression occurred in 12 patients in the idelalisib group and in 53 patients in the placebo group. The patients receiving idelalisib versus those receiving placebo had improved rates of overall response ( $81 \%$ vs. $13 \%$; $\mathrm{p}<0.001)$. On the basis of a review of imaging results by the independent review committee, the proportion of patients with a reduction of $50 \%$ or more in lymphadenopathy was significantly higher in the idelalisib group than in the placebo group (93\% vs. $4 \%$ ), for an odds ratio of $264(\mathrm{p}<0.001)$. The most impressive finding was that idelalisib and rituximab treatment had similar efficacy regardless of the presence of $17 p$ deletion or IGHV mutational status. A secondary endpoint overall survival at 12 months was $92 \%$ vs. $80 \%$; $\mathrm{p}=0.02$ (odds ratio, 29.92; $\mathrm{p}<$ $0.001)$. All responses were partial responses. Sixteen patients died while participating in the study: 4 patients (4\%) in the idelalisib group and 12 patients $(11 \%)$ in the placebo group. More than $90 \%$ of patients experienced at least one adverse event. The most common adverse events in the idelalisib group were pyrexia, fatigue, nausea, chills, and diarrhea. Grade 3 or 4 neutropenia, thrombocytope- 
International Journal of Hematology and Oncology

Table 2. Selected critical clinical trials of the novel molecular agents in CLL

\begin{tabular}{|c|c|c|c|c|c|c|}
\hline Drug & $\begin{array}{l}\text { Other } \\
\text { agents } \\
\text { in com- } \\
\text { bination }\end{array}$ & Clinical Trial & Phase & $\begin{array}{l}\text { Disease } \\
\text { Status }\end{array}$ & Response & Reference \\
\hline Ibrutinib & & $\begin{array}{l}\text { Safety of PCl-32765 in } \\
\text { chronic lymphocytic } \\
\text { leukemia }\end{array}$ & Phase lb/ll & $\begin{array}{l}>65 \text { y tx-naive } \\
\mathrm{R} / \mathrm{R} \text { or high } \\
\text { risk any age }\end{array}$ & ORR: $71 \%$ & $\begin{array}{l}\text { Byrd JC, et al. } \\
\text { N Engl J Med } \\
369: 32-42,2013\end{array}$ \\
\hline Ibrutinib & $\mathrm{BR}$ & $\begin{array}{l}\text { Safety and tolerability study } \\
\text { of PCl-32765 combined with } \\
\text { bendamustine/rituximab (BR) } \\
\text { in chronic lymphocytic } \\
\text { leukemia (CLL) }\end{array}$ & Phase lb & $\mathrm{R} / \mathrm{R}$ & $\begin{array}{l}\text { ORR: } 93 \% \\
\text { CR: } 13 \% \\
\text { PFS: } 90 \% \text { at } \\
12 \text { months }\end{array}$ & $\begin{array}{l}\text { Brown JR, et al } \\
\text { Blood 2013; } \\
120 \text { (Suppl1): } \\
\text { 525A }\end{array}$ \\
\hline Ibrutinib & Rituximab & $\begin{array}{l}\text { lbrutinib }(\mathrm{PCl}-32765) \text { in } \\
\text { combination with rituximab is } \\
\text { well tolerated and induces a } \\
\text { high rate of durable remission in } \\
\text { patients with high-risk chronic } \\
\text { lymphocytic leukemia }\end{array}$ & Phase II & High-risk & $\begin{array}{l}\text { ORR: } 95 \% \\
\text { CR: } 8 \% \\
\text { PFS: } 80 \% \\
\text { at } 14 \text { months }\end{array}$ & $\begin{array}{l}\text { Burger JA, et al } \\
\text { Blood 2013; } \\
120 \text { (Suppl. 1): } \\
675 A\end{array}$ \\
\hline $\begin{array}{l}\text { Ibrutinib } \\
\text { versus } \\
\text { ofatumum } \\
\text { (Resonate }\end{array}$ & nab & $\begin{array}{l}\text { lbrutinib versus ofatumumab } \\
\text { in previously treated chronic } \\
\text { lymphoid leukemia }\end{array}$ & Phase III & $\mathrm{R} / \mathrm{R}$ & $\begin{array}{l}\text { ORR: } 42,6 \% \\
\text { (lbrutinib) } \\
\text { vs } 4,1 \% \\
\text { (ofatumumab) } \\
\text { p<0.001 }\end{array}$ & $\begin{array}{l}\text { Byrd JC, et al } \\
\text { N Engl J Med } \\
371: 213-23,2014\end{array}$ \\
\hline Idelalisib & Rituximab & $\begin{array}{l}\text { A randomized, double-blind } \\
\text { and placebo-controlled study } \\
\text { of idelalisib in combination with } \\
\text { rituximab for previously treated } \\
\text { chronic lymphocytic leukemia } \\
\text { (CLL) }\end{array}$ & Phase III & $\mathrm{R} / \mathrm{R}$ & $\begin{array}{l}\text { ORR: } 81 \% \\
\text { (Idelalisib; R) } \\
\text { vs 13\% } \\
\text { (placebo, R) } \\
\text { Median PFS: } \\
5,5 \text { months in } \\
\text { placebo, NR in } \\
\text { idelalisib, R. } \\
\text { Median PFS: } \\
\text { 19,4 months }\end{array}$ & $\begin{array}{l}\text { Furman RR, et al } \\
\text { N Engl J Med } \\
370: 997-1007 \\
2014\end{array}$ \\
\hline Idelalisib & & $\begin{array}{l}\text { Idelalisib, an inhibitor of } \\
\text { phospha tidylinositol 3-kinase } \\
\text { p1108, for relapsed/refractory } \\
\text { chronic lymphocytic leukemia }\end{array}$ & Phase I & $\mathrm{R} / \mathrm{R}$ & $\begin{array}{l}\text { ORR: } 72 \% \\
\text { Median PFS } \\
15,8 \text { months }\end{array}$ & $\begin{array}{l}\text { Brown JR, et al } \\
\text { Blood 123: } 3390 \\
-3397,2014\end{array}$ \\
\hline Idelalisib & & $\begin{array}{l}\text { Randomized, placebo-controlled } \\
\text { study of Idelalisib plus } \\
\text { bendamustine and rituximab (BR) } \\
\text { is superior to BR alone in patients } \\
\text { with relapsed/refractory chronic } \\
\text { lymphocytic leukemia }\end{array}$ & Phase III & $\mathrm{R} / \mathrm{R}$ & $\begin{array}{l}\text { ORR: } 68 \% \\
\text { Idelalisib+BR } \\
\text { vs } 45 \% \text { BR } \\
\text { CR: } 5 \% \\
\text { Idelalisib+BR } \\
\text { vs 0\% BR } \\
\text { Median PFS } \\
23,1 \text { months }\end{array}$ & $\begin{array}{l}\text { December 03, } \\
\text { 2015; Blood: } \\
126 \text { (23) }\end{array}$ \\
\hline АВT-199 & Rituximab & $\begin{array}{l}\text { A phase } 1 b \text { study evaluating } \\
\text { the safety and tolerability of } \\
\text { ABT-199 in combination with } \\
\text { rituximab in subjects with } \\
\text { relapsed chronic lymphocytic } \\
\text { leukemia and small lymphocytic } \\
\text { lymphoma }\end{array}$ & Phase lb & $\mathrm{R} / \mathrm{R}$ & $\begin{array}{l}\text { 39\% CR/CRi } \\
\text { 5/7 CR patient } \\
\text { MRD negative }\end{array}$ & $\begin{array}{l}\text { Ma S, et al. } \\
\text { J Clin Oncol } \\
5 s, 2014 ; 32 \\
7013 \mathrm{~A}\end{array}$ \\
\hline
\end{tabular}

R/R: Relapsed Refractory; BR: Bendamustine, Rituximab; High-risk: del17p or TP53 mutation /treated or untreated), PRS <36 month after frontline immunotherapy or relapsed CLL with del11q 
nia, anemia, elevations in aminotransferases, and diarrhea occurred in $34 \%, 10 \%, 5 \%, 5 \%$, and $4 \%$ of patients, respectively. ${ }^{52}$

Andrew D Zelenetz et al presented the results of a randomized, placebo-controlled, phase III 115 study that evaluated the efficacy of IDELA added to $\mathrm{BR}$, a common regimen for relapsed/refractory (R/R) CLL. 416 patients (pts) with R/R CLL were enrolled. Patients were randomized to $\mathrm{BR}$ for 6 cycles Q 28 days $\left(B=70 \mathrm{mg} / \mathrm{m}^{2} \mathrm{D} 1\right.$, D2 of each cycle; $\mathrm{R}=375 \mathrm{mg} / \mathrm{m}^{2} \mathrm{C} 1$ and $\left.500 \mathrm{mg} / \mathrm{m}^{2} \mathrm{C} 2-6\right)$ and IDELA $150 \mathrm{mg}$ BID or placebo (administered continuously). A pre-specified interim analysis (IA) was performed with a median follow up 12 months demonstrating that PFS, the primary endpoint, and OS, a secondary endpoint, were superior in the investigational vs control arm with a safety profile consistent with prior reported studies. Rai stage III/ IV 46\%; median time since completion of last prior therapy 16 months; patients with $\operatorname{del}(17 \mathrm{p}) / \mathrm{p} 53$ mut $32.9 \%$, patients with unmutated IGHV $83.2 \%$, patients with refractory disease $29.8 \%$, median number of prior therapies: 2 (range: 1-13). Median PFS of IDELA + BR vs BR + placebo: 23 mo vs 11 mo $(\mathrm{HR}=0.33 ; \mathrm{p}<0.0001)$, median OS of IDELA $+\mathrm{BR}$ vs BR + placebo not reached for either arm $(\mathrm{HR}=0.55 ; \mathrm{p}=0.008)$. Addition of IDELA to BR was also beneficial in pts withoutdel(17p)/TP53mut. The most common all-grade AEs with IDELA + BR were neutropenia and pyrexia $(63.3 \%$ vs $41.5 \%)$, and with BR + placebo were neutropenia and nausea (53.6\% vs $34.4 \%$ ). The most common grade $\geq 3 \mathrm{AE}$ was neutropenia (59.9\%). Grade $\geq 3$ diarrhea with IDELA + BR was $7.2 \%$ and BR + placebo was $1.9 \% .^{53}$

Idelalisib has been approved by FDA in combination with rituximab for relapsed CLL in USA. In Europe, EMA also approved idelalisib-rituximab combination in relapsed/refractory patients as well as the front-line CLL treatment in the presence of $17 \mathrm{pDel}$ or TP53 mutation in patients unsuitable for the chemoimmunotherapy. EMA/Europe approved ibrutinib for chronic lymphocytic leukaemia patients who have received at least one previous treatment, and in patients who have genetic mutations in their cancer cells called 17p deletion or TP53 mutation that make them unsuitable for treatment with a combination of chemotherapy medicines and immunotherapy, for mantle cell lymphoma patients whose disease does not respond to or has come back after previous treatment. ${ }^{53}$

\section{Future Perspectives}

The pharmacological down-regulation of BCR activity is an attractive novel strategy for treating patients with B-cell malignancies particularly CLL. In addition to idelalisib and ibrutinib, BCL2 antagonists such as navitoclax is under progress for the management of CLL. Navitoclax is a potent inhibitor of pro-apoptotic proteins. However, its efficiency is limited by the adverse effect of thrombocytopenia. Therefore, the drug has been re-engineered into ABT-199 (venetoclax) with less profound thrombocytopenia due to selective inhibition of BCL-2 dependent tumor growth. Those molecules are under progress in distinct clinical drug development stages (Table 1 and Table 2).

The modulation of neoplastic signaling as well as the molecular interactions between CLL cells and stromal microenvironment will be translated into clinical trials that would be very helpful for the better management of the patients. The integration of the novel targeted agents for CLL therapy into sequential treatment approaches is also vital. Selected critical clinical trials of the novel molecular agents in CLL are depicted in Table 2. With the greater clinical experience following more widespread use of novel molecules, the optimal combination therapies in the treatment-naive and relapsed/refractory patients will be determined, resulting in more individualized therapeutic strategies for patients with CLL.

\section{REFERENCES}

1. Cheson BD. CLL and NHL: The end of chemotherapy? Blood 123: 3368-3370, 2014.

2. Young RM, Staudt LM. Ibrutinib treatment of CLL: The cancer fights back. Cancer Cell 26: 11-13, 2014.

3. Fruman DA, Cantley LC. Idelalisib-a PI3Kdelta inhibitor for Bcell cancers. N Engl J Med 370: 1061-1062, 2014.

4. Niemann CU, Wiestner A. B-cell receptor signaling as a driver of lymphoma development and evolution. Semin Cancer Biol 23: 410-421, 2013. 
5. Herman SE, Johnson AJ. Molecular pathways: Targeting phosphoinositide 3-kinase p110-delta in chronic lymphocytic leukemia. CCR 18: 4013-4018, 2012.

6. Burger JA. Inhibiting B-cell receptor signaling pathways in chronic lymphocytic leukemia. Curr Hematol Malig Rep 7: 2633, 2012.

7. Bodo J, Zhao X, Sharma A, et al. The phosphatidylinositol 3-kinases (PI3K) inhibitor GS-1101 synergistically potentiates histone deacetylase inhibitor-induced proliferation inhibition and apoptosis through the inactivation of PI3K and extracellular signal-regulated kinase pathways. Br J Haematol 163: 72-80, 2013.

8. Wang X, Ding J, Meng LH. PI3K isoform-selective inhibitors: next-generation targeted cancer therapies. Acta Pharmacol Sin 36: 1170-1176, 2015.

9. Akinleye A, Avvaru P, Furqan M, et al. Phosphatidylinositol 3-kinase (PI3K) inhibitors as cancer therapeutics. J Hematol Oncol 6: 88, 2013. doi: 10.1186/1756-8722-6-88

10. Chang JE, Kahl BS. PI3-kinase inhibitors in chronic lymphocytic leukemia. Curr Hematol Malig Rep 9: 33-43, 2014.

11. Burke RT, Meadows S, Loriaux MM, et al. A potential therapeutic strategy for chronic lymphocytic leukemia by combining Idelalisib and GS-9973, a novel spleen tyrosine kinase (Syk) inhibitor. Oncotarget 5: 908-915, 2014.

12. Burger JA, Okkenhaug K. Haematological cancer: idelalisibtargeting PI3Kdelta in patients with B-cell malignancies. Nat Rev Clin Oncol 11: 184-186, 2014.

13. Iyengar S, Clear A, Bodor C, et al. P110alpha-mediated constitutive PI3K signaling limits the efficacy of p110delta-selective inhibition in mantle cell lymphoma, particularly with multiple relapse. Blood 121: 2274-284, 2013.

14. Herman SEM, Mustafa RZ, Martyr SE, et al. Effective inhibition of tumor microenvironment interactions in CLL patients treated with The BTK inhibitor ibrutinib results in sustained inhibition of tumor proliferation and survival pathways. Blood 122: 118, 2013.

15. Ponader S, Burger JA. Bruton's tyrosine kinase: From X-linked agammaglobulinemia toward targeted therapy for B-cell malignancies. J Clin Oncol 32: 1830-1839, 2014.

16. Herman SE, Mustafa RZ, Gyamfi JA, et al. Ibrutinib inhibits B-cell receptor and NF-kappaB signaling and reduces tumor proliferation in tissue-resident cells of patients with chronic lymphocytic leukemia. Blood 123: 3286-3295, 2014.

17. Chang BY, Francesco M, De Rooij MFM, et al. Egress of CD19(+)CD5(+) cells into peripheral blood following treatment with the Bruton tyrosine kinase inhibitor ibrutinib in mantle cell lymphoma patients. Blood 122: 2412-2424, 2013.

18. Andritsos LA, Jaglowski SM. Ibrutinib inhibitor of tyrosine-protein kinase BTK oncolytic. Drugs Future 38: 359-366, 2013.

19. Arita A, McFarland DC, Myklebust JH, et al. Signaling pathways in lymphoma: pathogenesis and therapeutic targets. Future Oncol 9: 1549-1571, 2013.

20. Robak T, Robak P. BCR signaling in chronic lymphocytic leukemia and related inhibitors currently in clinical studies. Int Rev Immunol 32: 358-376, 2013.
21. Burger JA. Bruton's tyrosine tinase (BTK) Inhibitors in clinical trials. Curr Hematol Malig Rep 9: 44-49, 2014.

22. Schwarzbich MA, Witzens-Harig M. Ibrutinib. Recent Results Cancer Res 201: 259-267, 2014.

23. Woyach JA, Johnson AJ, Byrd JC. The B-cell receptor signaling pathway as a therapeutic target in CLL. Blood 120: 11751184, 2012.

24. Jain N, O'Brien S. Ibrutinib (PCl-32765) in chronic lymphocytic leukemia. Hematol Oncol Clin North Am 27: 851-860, 2013.

25. Brown JR. Ibrutinib (PCl-32765), the first BTK (Bruton's tyrosine kinase) inhibitor in clinical trials. Curr Hematol Malig Rep 8: 1-6, 2013.

26. Farooqui M, Lozier JN, Valdez J, et al. Ibrutinib (PCl 32765) rapidly improves platelet counts in chronic lymphocytic leukemia/small lymphocytic lymphoma (CLL/SLL) patients and has minimal effects on platelet aggregation. Blood 120: 21, 2012.

27. Akinleye A, Furqan M, Adekunle O. Ibrutinib and Indolent Bcell lymphomas. Clin Lymphoma Myeloma Leuk 14: 253-260, 2014.

28. O'Brien S, Furman RR, Coutre SE, et al. Ibrutinib as initial therapy for elderly patients with chronic lymphocytic leukaemia or small lymphocytic lymphoma: an open-label, multicentre, phase 1b/2 trial. Lancet Oncol 15: 48-58, 2014.

29. Novero A, Ravella PM, Chen Y, et al. Ibrutinib for B cell malignancies. Exp Hematol Oncol 3: 4, 2014. doi: 10.1186/21623619-3-4.

30. Woyach JA, Bojnik E, Ruppert AS, et al. Bruton's tyrosine kinase (BTK) function is important to the development and expansion of chronic lymphocytic leukemia (CLL). Blood 123: 1207-1213, 2014.

31. Burger JA, Buggy JJ. Bruton tyrosine kinase inhibitor ibrutinib (PCl-32765). Leuk. Lymphoma 54: 2385-2391, 2013.

32. Niemann CU, Biancotto A, Chang BY, et al. Cytokine and Tcell phenotypic changes upon in vivo ibrutinib therapy for CLL - Targeting both CLL cells and the tumor-microenvironment. Blood 122: 2856, 2013.

33. Niemann CU, Jones J, Wiestner A. Towards targeted therapy of thronic tymphocytic teukemia. Adv Exp Med Biol 792: 259291, 2013.

34. Bagcchi S. Ibrutinib monotherapy in chronic lymphoid leukaemia. Lancet Oncol 15: 312, 2014.

35. Davids MS, Brown JR. Ibrutinib: A first in class covalent inhibitor of Bruton's tyrosine kinase. Future Oncol 10: 957-967, 2014.

36. Seda V, Mraz M. B cell receptor (BCR) signalling and its crosstalk with other pathways in normal and malignant cells. Eur $J$ Haematol 94: 193-205, 2015.

37. Rajeeve V, Vendrell I, Wilkes E, et al. Cross-species proteomics reveals specific modulation of signaling in cancer and stromal cells by phosphoinositide 3-kinase (PI3K) inhibitors. Mol Cell Proteomics 13: 1457-1470, 2014.

38. Bader AG, Kang S, Zhao L, Vogt PK. Oncogenic PI3K deregulates transcription and translation. Nat Rev Cancer 5: 921 929, 2005. 
39. Cheng S, Ma J, Guo A, et al. BTK inhibition targets in vivo CLL proliferation through its effects on B-cell receptor signaling activity. Leukemia 28: 649-657, 2014.

40. Han TT, Fan L, Li JY, Xu W. Role of chemokines and their receptors in chronic lymphocytic leukemia Function in microenvironment and targeted therapy. Cancer Biol Ther 15: 3-9, 2014.

41. Coelho V, Krysov S, Steele A, et al. Identification in CLL of circulating intraclonal subgroups with varying B-cell receptor expression and function. Blood 122: 2664-2672, 2013.

42. Hoellenriegel J, Meadows SA, Sivina M, et al. The phosphoinositide 30-kinase delta inhibitor, CAL-101, inhibits B-cell receptor signaling and chemokine networks in chronic lymphocytic leukemia. Blood 118: 3603-3612, 2011.

43. Sehgal L, Mathur R, Braun FK, et al. FAS-antisense 1 IncRNA and production of soluble versus membrane Fas in B-cell lymphoma. Leukemia 28: 2376-2387, 2014.

44. Wodarz D, Garg N, Komarova NL, et al. Kinetics of chronic lymphocytic leukemia (CLL) cells in tissues and blood during therapy with the BTK inhibitor ibrutinib. Blood 123: 41324135, 2014.

45. Rossi D, Gaidano G. Lymphocytosis and ibrutinib treatment of CLL. Blood 123: 1772-1774, 2014.

46. Mustafa RZ, Herman SEM, Jones J, et al. Ibrutinib inhibits B-cell adhesion and causes an efflux of chronic lymphocytic leukemia cells from the tissue microenvironment into the blood leading to a transient treatment-induced lymphocytosis. Blood 122: 674, 2013.

47. Brown JR, Byrd JC, Coutre SE, et al. Idelalisib, an inhibitor of phosphatidylinositol 3-kinase p110delta, for relapsed/refractory chronic lymphocytic leukemia. Blood 123: 3390-3397, 2014.

48. Ghia P. Ibrutinib: better combined with other drugs? Lancet Oncol 15: 1043-1044, 2014.
49. Smith DD, Goldstein L, Cheng M, et al. Modeling absolute lymphocyte counts after treatment of chronic lymphocytic leukemia with ibrutinib. Ann Hematol 94: 249-256, 2015.

50. O'Brien SM, Lamanna N, Kipps TJ, et al. A phase 2 study of idelalisib plus rituximab in treatment-naive older patients with chronic lymphocytic leukemia. Blood 126: 2686-2694, 2015.

51. Goede V, Fischer K, Engelke A, et al. Obinutuzumab as frontline treatment of chronic lymphocytic leukemia: updated results of the CLL11 study. Leukemia 29: 1602-1604, 2015.

52. Furman RR, Sharman JP, Coutre SE, et al. Idelalisib and rituximab in relapsed chronic lymphocytic leukemia. New Engl $J$ Med 370: 997-1007, 2014.

53. Zelenetz AD, Robak T, Coiffier B, et al. Idelalisib plus bendamustine and rituximab (BR) is superior to $\mathrm{BR}$ alone in patients with relapsed/refractory chronic lymphocytic leukemia: Results of a phase 3 randomized double-blind placebo-controlled study. Blood 126: LBA-5, 2015.

\section{Correspondence}

Dr. Nilgun Sayinalp

Hacettepe University, Faculty of Medicine

Division of Hematology,

Sihhiye, ANKAR / TURKEY

Tel: (+90-312) 3051543

e-mail: nsayinal@hacettepe.edu.tr 